\title{
DIGITAL DEVICE OWNERSHIP AND LEARNING ENVIRONMENT PREFERENCES OF STUDENTS IN SOUTH AFRICA AND GHANA
}

\author{
Dr. Simon-Peter Kafui AHETO \\ Faculty of Science and Technology Education \\ University of Cape Coast \\ Cape Coast, Ghana \\ Dr. Johannes CRONJE \\ Faculty of Informatics and Design \\ Cape Peninsula University of Technology \\ Cape Town, South Africa
}

\section{ABSTRACT}

This paper explores differences in access to technology and configuration of preferences for learning environments among design students in two universities of technology in South Africa (ISA) and Ghana (IG). Laptops and Smartphones ownership influenced and supported design students' learning. In IG, there was a $97 \%$ Laptop ownership as against $69 \%$ in ISA. IG does not have computer laboratories; hence Laptop ownership is a prerequirement for Design programs. Oppositely, ISA has fourteen computer laboratories for Design programs. There is no statistically significant difference between male and female design students in their choice of learning environments for academic success. Design students are not enthusiastic about accessing library resources via handheld devices. Towards academic success, students ranked low, their institutions' Learning Management Systems. We recommend a blended approach when designing learning environments for Design Education, while promoting the use of media platforms for content management due to device ownership among students.

Keywords: Device ownership, design, design students, higher education, learning environment.

\section{INTRODUCTION}

Technological advances are defining a new approach to education. The technological revolution has caused continuous discussions among practitioners viz-a-viz the role of technology in enhancing education (Miller, 2016; Shelly, Gunter \& Gunter, 2012; Wheeler, 2012; Yumurtaci, 2017). The affordances of certain emerging technologies such as social media in Higher Education have been motivated by the well-connected and networked kind of students we have (Boyd, 2014; Bozanta \& Mardikyan, 2017, Johnson, Becker, Estrada \& Freeman, 2014; Koole \& Stack, 2016). This connectedness can be observed from the kind of devices students use and the kind of activities mediated through these tools, which also impacts on their learning.

In the $21^{\text {st }}$ century, it is common to see students try out various technologies for their personal, academic and social lives. Arguments by Barry, et al. (2015) indicate that exploring reasons about the extent to which students use technology in teaching and learning is good recipe for curriculum design that leverages on students technological capabilities and uses. This paper contributes an understanding of technological underpinnings with a relative effect on ingenious "curricula design and delivery" in Universities of Technology (UoTs) where research is scanty (Rambe, 2016, p. 86); therefore, seeks to explore the differences among two groups of design students and their 
impact on design education and delivery in two Universities of Technology (UoTs) in South Africa and Ghana. The study considered students' device ownership, use and their configuration of learning environment preferences using technology.

\section{Universities of Technology and Design Education}

The position of Universities of Technology in Higher Education is uniquely designed to strategically train, diversify and equip students with knowledge, skills and creativity underpinned by technology transfer. According to the South African Technology Network (SATN, 2008, p. 16), the focus of UoTs is "on the study of technology from the viewpoint of various fields of study, rather than a particular field of study" since technology affects all aspects of human life and existence. Design Education is one of such fields of study offered by UoTs that is broad in scope and affects humans in various ways.

Design Education in UoTs provides a repertoire of knowledge, skills and attitudes to students through "future-orientated curriculum" by pushing the limits of "technology forward but also domesticating it" from the realms of imagination and creativity to concretized "sustainable and meaningful social changes" (Baynes, 2010; Manzini, 2015). Positive consequences of students' proficiency in technology use in their learning environments impact their work output in practice. The imperative place of Design Education in our current existence is needed to solve complex challenges in our "economic, social and political systems"through the work of designers, proper use of technologies and planning (Munshi, 2010). The role of Design Education share similar significance of three of Brook's (2000) characteristics of UoT being:

$>$ Multi-level entry and exit points for students;

$>$ Concerned primarily with the development of vocational/professional education;

$>$ Technological capabilities as important as cognitive skills.

Hitherto, design in general was only seen as a vocation not a profession due to apprenticeship. Here, UoTs have married a number of attributes: vocation, profession, technology and creativity in design education curriculum to make it practical and bias towards industry. Simply, UoT and Design Education strive to use technology to achieve their purposes via suitable technologies to better the lives of people and society. In the wake of pervasive technological advancement and the reason that Design Education has always functioned to solve 'local' challenges with 'localized' technologies, it is not out of place to explore the technological devices employed in a modern day Design Education in two leading Design institutions in Africa. In spite of the fact that design has gradually changed from studio-based to digital formats, very little is known about the kind of devices owned and used by design students and the preferred learning environments within which students learn best (Appiah, 2014; Ward, 1990).

\section{ICT Resources}

Device ownership

Despite the financial burden on schools, parents and teachers, device ownership by students continues to play a significant role in the teaching and learning process of students. In the bid to achieve learning outcomes, parents, school authorities and other stakeholders have invested in ICT infrastructure which includes Internet connectivity and other devices (Gikas \& Grant, 2013; Salaway \& Caruso, 2007). In their research, Witecki and Nonnecke (2015, p. 73) posited that though "ownership and use" of devices by Higher Education students were not only on the ascendency (Cross, Sharples, Healing, 2015; Dahlstrom, Grunwald \& Vockley, 2011), it also related strongly to lower course engagement. Recently, Sydney Grammar School in Australia announced that it had banned students from having laptops in school due to its role as a preventive agent to class engagement and absolute misappropriation of funds (Bita, 2016).

In contrast, other studies have held that student ownership regimes of new technologies such as computer, mobile devices and computer applications are crucial in curriculum designs and delivery (Sharples et al., 2014; Shelly, Gunter \& Gunter, 2012). Access to 
educational resources like e-books from libraries is increased due to the proliferation of computer and mobile device ownership (Baddeley, 2012; Hamblen, 2011; Leye, 2007). According to the 2014 NMC Horizon report, Bring Your Own Device (BYOD) promotes learner-centric learning environments where learner takes charge of his/her learning (Johnson, Adams Becker, Estrada \& Freeman 2014, p. 34). Device ownership and use encourages "lecturer control" and self-directed learners (Sharples et al., 2014). The issue of device ownership in higher education is becoming more of a socio-cultural issue rather than a pedagogical issue. On the other hand, Oliver (2011) also contends that technology use in our educational landscape is exaggerated. Oliver's point may serve as a support to Witecki and Nonnecke (2015) and Bita's (2016) side of the debate.

There is a range of digital devices commonly owned and used by students. These devices include laptop and Smartphone or tablets (Sharples et al., 2014); cellphones (Witecki \& Nonnecke, 2015). Compelling reasons such as convenience of getting connected to educational resources via portable devices may not be the only reason for device ownership. Other reasons include students' ability to access news, calls, instant messaging, surfing, gambling, social media and data storage (Barry, Murphy \& Drew, 2015).

\section{Handheld devices}

Handheld devices play various roles (educational and non-educational) in the dispensation of higher education. Despite ongoing debates on the prospects and limitations of educational use of handheld devices for higher education (Gupta \& Koo, 2010); there are continuous exploration, promotion, integration and abolishment of handheld devices for teaching and learning in higher education (Gaskell, 2015).

Among the advantages, include the offer of handheld devices to current students a great opportunity to "vary their study location and to study 'on the move'"' (Evans, 2008, p. 492). According to Gaskell (2015), the use of mobile technologies must be seen from two perspectives: Access and Administration; and Teaching and Learning. For instance, the use of handheld devices by students for access to library resources (Billings, 2003; Cummings, Merrill \& Borrelli, 2010; West, Hafner \& Faust, 2006), course management systems (Ally, 2009), and information dissemination and the total management of student communication (Motiwalla, 2007, p. 596) align with the former. Other beneficial uses of handheld devices include Microblogs (Paliktzoglou \& Suhonen, 2014), Podcasts (Evans, 2008; Hsu, 2015), e-texts (Hsu, 2015). Four benefits of handheld devices for academic reasons are identified by Dahlstrom et al. (2011) as:

$>$ Easy access to resources and reducing the burden of administration tasks;

$>$ Improvement in productivity;

$>$ Becoming more connected; and

$>$ Enabling learning to be more creative, authentic and reflective.

Nonetheless, there are concerns as to the use of handheld devices in higher education. Concerns such as cost of devices and Internet are very legitimate. In Africa, some students will naturally find it difficult if not impossible to access Internet. Though there is a gradual paradigm towards free access to public Wi-Fi, it is still a major challenge for these facilities to be accessed by students for academic work. Accessing library resources may also be a barrier for students since some handheld devices may have smaller screens making navigation complex. More so, rotational functions of certain devices may pose accessibility problems (Falloon, 2015). Gupta and Koo (2015) also identified downloads as challenge for handheld users in education. On the contrary, McKnight, (2011, p. 4) argues that:

"Greater emphasis is being placed on rendering library digital content, including web pages providing access to online services, to formats that can be used by mobile devices, such as smart phones and personal digital assistants." 
It is not clear if libraries are going to achieve their targets to allow access to library resources to be fully functional on Smartphones and personal digital assistants since challenges to digital access keep recurring in recent literature. While drawing on the strengths and limitations of handheld devices, Walmsley's (2014) argument of students being isolated from each other by such devices raises another set of 'dispute'. Other literature sources suggest that handheld devices promote student collaboration, effectiveness in access and administration of resources like library, course management and checking of grades (Falloon, 2015; Hwang, 2015; Lai \& McKnight, 2011).

In a study to find out the effectiveness of integrating podcasting in teaching and learning in higher Education, Evan (2008) found out that the use of iPod for podcasting was widespread. Lai and Hwang's experiment to improve students' art design performance via handheld devices revealed that tablet computers promote "students' learning achievement, learning motivation and meta-cognitive awareness. "Students also learned best through an "interactive peer-assessment" (Lai \& Hwang, 2015, p. 154). Recently Cross et al. (2015) reported a rapid increase the ownership of tablets among students. They further found changes in students' study habit with the use of handheld devices with statistical significant differences between course areas.

Motiwalla's (2015) exploratory study sought to find out about the students' experiences with wireless/handheld $(\mathrm{W} / \mathrm{H})$ computing devices. The results indicated that students had major challenges with the W/H user-interface of the application therefore; Motiwalla proposed an improvement in user-interface of $\mathrm{W} / \mathrm{H}$ applications with additional features such as interactive voice recognition. Though voice applications may be a source of distraction to some students depending on the learning environment (Falloon, 2015), Motiwalla's findings can be corroborated by earlier suggestions by Evans (2008) who posits that voice in handheld applications for students allow them to associate text with voice. McKnight (2011) reveals differences in paradigm in terms of the kinds of students who access libraries; the diversity cover gender, age, mode of study sometimes due to barriers or varied experiences of students; however, digital devices somewhat bridge these gaps and differences.

Leeson (2006) posits that e-readers or tablets there are no differences between reading on Tablets or e-readers in comparison to reading on paper. Liang \& Huang's (2014, p. 218) research established that e-book reading has the propensity to encourage "student's retrieval as compared with reading printed books. "Piper, Jepkemei, Kwayumba \& Kibukho (2015) also found statistically significant differences in the use of e-readers for teaching and learning of English and Swahili. On the other hand, Huang, Liao, Huang \& Chen (2014) recommends that due to the larger screens of Tablet PCs than Smartphones and Personal Digital Devices, some educational activities such as reading texts and varied multimedia audiovisual purposes should be best performed on Tablet PCs. However, none of the above researchers explored device ownership and learning environment preferences of design students in UoTs or across two countries. Again, none of the researches sought to find out differences between two Design institutions in terms of enhancement of academic work via handheld mobile devices.

\section{Learning Environments in Higher Education}

"The term environment denotes the totality of the surroundings and conditions in which something or someone lives or functions" (Warger \& Dobbin, 2009, p. 6). A learning environment defines the boundaries, resources, conditions and practices within which knowledge, skills and attitudes can be promoted. Face-to-Face, blended and online modes have been identified as learning environments by several authors (Boyd, 2014; Herrington, Reeves \& Oliver, 2010; Salter, Pang \& Sharma, 2009; Shelly et al., 2012; Warger \& Dobbin, 2009). This research adopts EDUCAUSE's definition of learning environment which goes beyond learning management systems but one with no online components or completely online or one with some online components (Eden \& Bichsel, 2014). Discussions on learning environments in Higher Education are highly contentious issues since they immensely 
affect students' learning connections and behavior in a multifaceted technological environment (Aheto \& Cronje, 2014).

Karchmer-Klein and Shinas (2012) believe that students' reliance on the Internet as their 'master teacher' invariably assists their cognitive, affective and psychomotor performances (Karchmer-Klein \& Shinas, 2012, p. 391-392). Sperber (2005) noted that the focus in institutions of higher learning is more towards cognitive development with little emphasis on the other aspects. Bridging this gap by UoTs calls for "successful deployment of educational use of technology depending on the technical proficiency and pedagogical techniques associated with it" (Warger \& Dobbin, 2009, p. 7) which also strongly relates to design education. Properly planned learning environment are useful elements in the promotion of students engagement or participation in achieving learning tasks (Lee \& Kim, 2016). However, the above studies did not highlight on learning environment preferences for design students in Higher Education.

\section{OBJECTIVES}

The objectives specified for the current study are:

1. To explore the extent to which device ownership and use play a role in the learning preferences among design students in the two universities of technology in South Africa and Ghana.

2. To identify differences between the two institutions' design students in terms of their learning environment preferences.

3. To find out the differences between male and female design students in terms of their learning environment preferences in the two institutions.

4. To identify differences between the two institutions' design students in the use of handheld mobile devices to enhance academic work.

\section{Research Question}

To what extent does device ownership and use play a role in the learning preferences among design students in the two universities of technology?

\section{Hypotheses}

The following null hypotheses guided the study:

1. There is no statistically significant difference between the two institutions' design students in terms of learning environment preferences.

2. There is no statistically significant difference between male and female design students in terms of learning environment preferences.

3. There is no statistically significant difference between the two institutions' design students in the use of handheld mobile devices to enhance academic work.

\section{METHOD}

This section covers how this study was carried out, people involved in study and how they were selected. The section also caters to what went into the analysis for the research.

\section{Research Design}

This study was guided by a research question and three hypotheses. The descriptive mixed methods research design was used in order to explore the differences in access to technology and configuration of preferences for learning environments among design students. The main aim of using the research design was to support findings from numeric analysis with narratives from the focus group interviews (Plowright, 2011; Yin, 2014). The use of the descriptive mixed methods was to get in-depth and adequate insight into the current state of digital device ownership and the learning preferences of students studied. Again, the study capitalized on the strengths of both numeric and narrative results to complement each other in the analysis of results. 'ISA' and 'IG' are pseudonyms used to represent the two universities of technology in South Africa and Ghana in this study. The 
study followed ethical standards. Ethical clearance for the research was granted by the Faculty of Informatics and Design Research Ethics Committee of Cape Peninsula University of Technology.

\section{Data Collection Tools}

The survey instrument dubbed Survey Questionnaire was adapted with permission from EDUCAUSE Centre for Applied Research's (ECAR) Study of Undergraduate Students and Technology Survey, 2014. The questionnaire was adapted because the survey items addressed digital device ownership and learning environment issues in Higher Education. To establish the validity of the questionnaire, the instrument was subjected to the researchers' Faculty Research Committee for review and ethical clearance. The committee established whether the instrument was appropriate and comprehensive to meet the objectives of the study, taking into account, the population. A total of seventeen survey questions were used to solicit responses for the numeric data. Items ranged from questions on device ownership, uses and importance of digital devices for academic success and their preferences for learning environments. In selecting sample for the numeric data, the same set of survey questions were administered via Google Web-Based Survey Questionnaire (WBSQ) in ISA and Paper-Based Survey Questionnaire (PBSQ) mode in IG. The use of a WBSQ had some advantages over the PBSQ in that it was easier for respondents from ISA to access labs which they always use on a daily bases. As can be corroborated by Kiesler and Sproull (1987, p. 404), the WBSQ was cheaper in terms of cost, discouraged blank answers (mandatory fields) and also "eliminated human or technological transcription" relative to PBSQ.

The reliability co-efficient of Cronbach's alpha (a) for the survey instrument was 0.81 , this value is above the acceptable minimum level of 0.7 (Saunders, Lewis \& Thornhill, 2012). Cronbach's alpha is widely used to check the internal consistency for survey items (Mitchell, 1996). The questions also covered demographic details and 3 to 4-point Likert scale.

An in-depth questioning technique was employed to gather narrative data from two focus group interviews (Krueger, 1986). Each session, lasting for about 40 minutes in the two institutions was audio recorded and later transcribed for analysis lasted for about 40 minutes. The focus group interviews were in-depth and had unstructured questions to further probe issues on the ownership, uses and importance of digital devices and justification of their choices of learning preferences. Responses were categorized into themes that were used to support data discussions from the numeric analysis.

\section{Sample}

Data was used from an ongoing study on the characteristics and technological usage of students in their Personal Learning Networks. Two Universities of Technology from South Africa (ISA) and Ghana (IG) were purposely sampled due to the similar characteristics they possessed. The institutions were included in the study because they both offered design courses in leading Universities of Technology in their countries. Sample covered 121 students from a population of design undergraduate students in ISA and IG (second-year students). Two groups of the students ( 7 in a group) from each of the institutions who responded to the survey questionnaire agreed to be part of a follow-up focus group interview. They were randomly selected from the population for the interviews.

Due to the Paper-Based Survey Questionnaire (PBSQ) adapted for use in IG, Krejcie and Morgan's sampling frame was used as a benchmark to arrive at a sample size for this study. Krejcie and Morgan (1970) suggest that for a population of 75, the sample must be 63 and for a population of 80, the sample must be 66. In this study, the sample of 70 for PBSQ for a population of 78 far exceeded the threshold suggestions by Krejcie and Morgan (1970). Since web-based surveys are not strictly obsessed about probability sampling techniques, sampling for the WBSQ was based on volunteer sampling with no such thing as sampling calculations (Lefever, Dal \& Matthiasdottir, 2007). 
Table 1. Population and sample of participants

\begin{tabular}{lllll}
\hline \multirow{2}{*}{ Institutions } & \multirow{2}{*}{ Population } & \multicolumn{3}{c}{ Sample } \\
\cline { 3 - 5 } & & Male & Female & Total \\
\hline ISA & 72 & 12 & 39 & 51 \\
IG & 78 & 42 & 28 & 70 \\
Total & 150 & 54 & 67 & 121 \\
\hline
\end{tabular}

Table 1 describes sample in the mixed methods study where the researchers used focus group interviews and survey.

\title{
Data Analysis
}

Descriptive and inferential statistics were used in analyzing numeric data from the survey questions. Data were analyzed and represented in table of percentages, means, charts and standard deviation and $t$-values. Questionnaires were coded such a Likert scale (see Table 4) ranged in value from Not at all important (1) to Very important (4). All three hypotheses were inferentially analyzed and interpretation done to elicit the kind of differences that existed between the variables. Data from the focus group interviews were treated as narratives and thematically categorized to support the results and discussions from the numeric data and analysis.

\section{RESULTS AND DISCUSSIONS}

\section{Demographic Details}

ISA (Institution in South Africa) and IG (Institution in Ghana) are pseudonyms for two Universities of Technology (UoT) used in this study. The two institutions are

\begin{abstract}
"mandated to equip students to understand life, and not only become backroom theoretician with little understanding of the real world [sic] basically they endow students with the know-how to fabricate things (this includes creating and developing new technologies) through focusing on the study of technology from the viewpoint of various fields of study, rather than a particular field of study"(SATN, 2008).
\end{abstract}

The selection of the two UoTs was based on their shared mission. Both are in developing countries, but one is the only institution of its kind in its country (IG) and can therefore choose to set stringent criteria for existing knowledge on device ownership, while the other (ISA) has as a part of its mission the redress of past imbalances and thus less stringent criteria for entry qualifications and device ownership.

Currently, both institutions are diverse in terms of the design courses (up to postgraduate levels) offered. Though IG has existed for more than 60 years, they have two design departments: Communication Design and Architectural Design; ISA is fairly new and slightly above 10 years with up to six design departments: Graphic, Industrial, Interior, Jewellery, Surface and Fashion Departments. Student respondents for the study are all second year design students from both institutions.

The research question driving this paper states that: to what extent does device ownership and use play a role among design students in the two universities of technology? 
Survey question 1

What are the devices ISA and IG design students own?

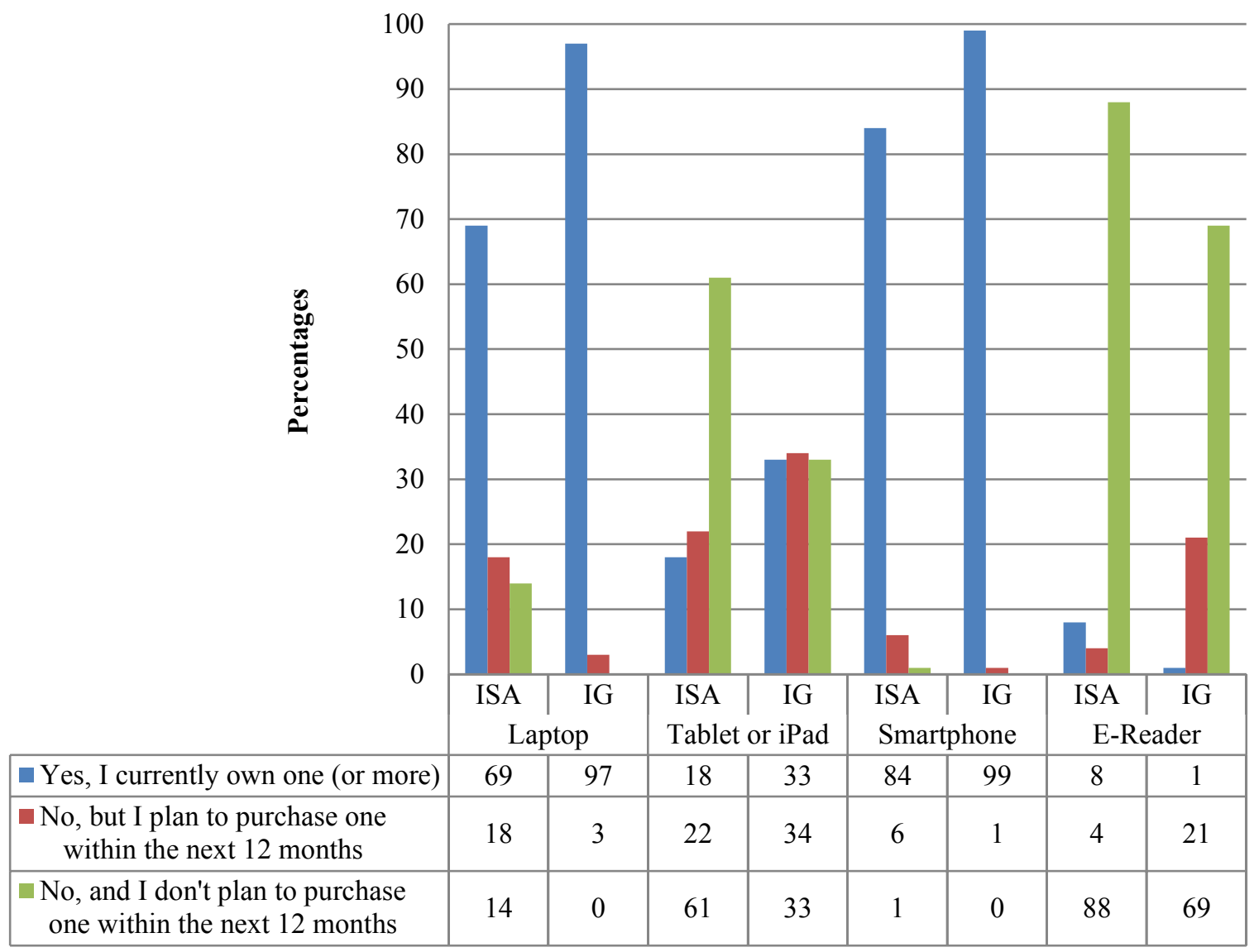

Figure 1. Device Ownership

As can be seen in Figure 1, a good number of students in both institutions own Smartphones followed by Laptops. Less than half of the population own Tablets or iPads while a good number of the participants have no plans of owning an E-Reader. Mobile phones and Laptops are widespread and effective technological tools for communication. The results are consistent with Shelly et al.'s (2012) report that students use computers, laptops to connect with their community which sometimes comprise parents, friends learning resources and other stakeholders. Results in Figure 4 differ from Caruso and Salaway (2008) who recorded Laptops $(\mathbf{8 0 . 5 \% )}$ as popularly owned.

Smartphones may be the most commonly owned technological tool because; they use applications that are tailored to specific needs such as capturing images, videos, notes. Results on Tablets or iPad (ISA $=18 \%$; IG $=33 \%$ ) and E-reader $(I S A=8 \% ; I G=10 \%)$ and inconsistent with findings of Cross et al. (2015) reported $72 \%$ and $37 \%$ ownership among respondents respectively. These differences may be attained because Cross et al. (2015) context was outside Africa. Perhaps in the future, design students will boast increase in Tablets or iPads ownership for a 'handy' design work and ideation since that may fall between functions of a phone and a laptop. But it must be mentioned that Smith and Caruso (2010) in a study in the United States of America reported $98 \%$ computer ownership of students (undergraduate) which is consistent ownership of Laptop computers of IG (97\%).

In Sub-Saharan Africa, there are records of increasing support from organizations for ICT integration in Higher Education (Muianga et al., 2013). For instance, telecommunication 
providers sometimes give free data packages to their clients for accessing certain platforms with educational values such as Wikipedia (Airtel, 2013; MTN Ghana, n.d). Since mobile phones and Laptops allow for multiple communications, students have found educational use for them. In IG there are no dedicated computer laboratories for design courses making ownership of a personal computer a basic requirement (Kong et al., 2014) which is not the same for ISA which has up to fourteen computer laboratories including four Mac laboratories for design courses with Internet connection and other facilities. Indeed, findings about dedicated computer laboratories are regular with Kong et al.'s (2014) second type of policy implication that affects ownership of personal devices. Most of the design students possibly do not own tablets or iPads and E-readers because the Smartphone and Laptop is enough to perform all other functions tablets, iPads and Ereaders perform. Some of the design software are also not compatible with tablets, iPads and E-readers as compared to laptops. Ownership of Laptop results is consistent with assertions by Nilson and Weaver (2005) and Brown (2009) who see Laptop as transformative tool in education.

\section{Survey question 2}

How are the devices owned by ISA and IG design students important to their academic success?

Table 2. Uses of devices for academic success

\begin{tabular}{|c|c|c|c|c|c|c|c|c|c|c|c|c|}
\hline \multirow[b]{2}{*}{ Device } & \multicolumn{3}{|c|}{$\begin{array}{c}\text { Haven't used in the past } \\
\text { year }\end{array}$} & \multicolumn{3}{|c|}{$\begin{array}{l}\text { Use for academic and } \\
\text { other purposes }\end{array}$} & \multicolumn{3}{|c|}{$\begin{array}{l}\text { Use for academic } \\
\text { purposes only }\end{array}$} & \multicolumn{3}{|c|}{$\begin{array}{c}\text { Use for other purposes } \\
\text { only }\end{array}$} \\
\hline & ISA & IG & Total & ISA & IG & Total & ISA & IG & Total & ISA & IG & Total \\
\hline Laptop & $\begin{array}{l}8 \\
(16 \%)\end{array}$ & $\begin{array}{l}0 \\
(0 \%)\end{array}$ & $\begin{array}{l}8 \\
(7 \%)\end{array}$ & $\begin{array}{l}36 \\
(71 \%) \\
\end{array}$ & $\begin{array}{l}68 \\
(97 \%) \\
\end{array}$ & $\begin{array}{l}104 \\
(86 \%) \\
\end{array}$ & 6 & $\begin{array}{l}2 \\
(3 \%)\end{array}$ & $\begin{array}{l}8 \\
(7 \%)\end{array}$ & $\begin{array}{l}1 \\
(2 \%)\end{array}$ & $\begin{array}{l}0 \\
(0 \%)\end{array}$ & $\begin{array}{l}1 \\
(1 \%)\end{array}$ \\
\hline $\begin{array}{l}\text { Tablet or } \\
\text { iPad } \\
\end{array}$ & $\begin{array}{l}27 \\
(53 \%)\end{array}$ & $\begin{array}{l}21 \\
(30 \%)\end{array}$ & $\begin{array}{ll}48 \\
(40 \%)\end{array}$ & $\begin{array}{ll}16 \\
(31 \%) \\
\end{array}$ & $\begin{array}{ll}40 \\
(57 \%)\end{array}$ & $\begin{array}{ll}56 \\
(46 \%) \\
\end{array}$ & $\begin{array}{l}6 \\
(12 \%)\end{array}$ & $\begin{array}{l}7 \\
(10 \%) \\
\end{array}$ & $\begin{array}{ll}13 \\
(11 \%)\end{array}$ & $\begin{array}{l}2 \\
(4 \%)\end{array}$ & $\begin{array}{l}2 \\
(3 \%)\end{array}$ & $\begin{array}{ll}4 \\
(3 \%)\end{array}$ \\
\hline Smartphone & $\begin{array}{l}4 \\
(8 \%)\end{array}$ & $\begin{array}{l}0 \\
(0 \%)\end{array}$ & $\begin{array}{l}4 \\
(3 \%)\end{array}$ & $\begin{array}{l}37 \\
(73 \%)\end{array}$ & $\begin{array}{l}65 \\
(93 \%)\end{array}$ & $\begin{array}{l}102 \\
(84 \%)\end{array}$ & $\begin{array}{l}3 \\
(6 \%)\end{array}$ & $\begin{array}{l}0 \\
(0 \%)\end{array}$ & $\begin{array}{l}3 \\
(2 \%)\end{array}$ & $\begin{array}{l}7 \\
(14 \%)\end{array}$ & $\begin{array}{l}5 \\
(7 \%)\end{array}$ & $\begin{array}{l}12 \\
(10 \%)\end{array}$ \\
\hline E-reader & $\begin{array}{l}32 \\
(63 \%)\end{array}$ & $\begin{array}{l}31 \\
(44 \%)\end{array}$ & $\begin{array}{l}63 \\
(52 \%)\end{array}$ & $\begin{array}{l}11 \\
(22 \%)\end{array}$ & $\begin{array}{l}27 \\
(39 \%)\end{array}$ & $\begin{array}{l}38 \\
(31 \%)\end{array}$ & $\begin{array}{l}0 \\
(0 \%)\end{array}$ & $\begin{array}{l}8 \\
(11 \%)\end{array}$ & \begin{tabular}{|l|}
8 \\
$(7 \%)$ \\
\end{tabular} & $\begin{array}{l}8 \\
(16 \%) \\
\end{array}$ & $\begin{array}{l}4 \\
(6 \%) \\
\end{array}$ & $\begin{array}{l}12 \\
(10 \%)\end{array}$ \\
\hline
\end{tabular}

Table 2, shows that more students use their Laptops followed by Smartphones for academic and other purposes as against academic work only. Though Tablet or iPad and E-readers are also used for same purposes by students, not many of them used it for academic work. The findings are inconsistent with Nilson and Weaver (2005) and Shelly et al. (2012) because Laptops are gradually becoming basic classroom necessities. The findings also highlight the capacity of students' creative abilities (Eton, 2012; Farrant, 1980; Shelly et al., 2012). Although these tools enhance the creative abilities of students to promote learning, the numerous applications they offer also allow them to be multitasking, which is inconsistent with Farrant (1980) who does not recommend multitasking as a very effective way of learning. Other non-academic purposes that these tools bring are videos, games, music, chats, surfing the Internet, among others.

\section{Survey question 3}

How are handheld mobile devices important to ISA and IG design students towards academic success? 
Table 3. Importance of devices used for academic success

\begin{tabular}{|c|c|c|c|c|c|c|c|c|c|c|c|c|c|c|c|}
\hline \multirow[b]{2}{*}{ Device } & \multicolumn{3}{|c|}{$\begin{array}{l}\text { Not at all } \\
\text { important }\end{array}$} & \multicolumn{3}{|c|}{ Not very important } & \multicolumn{3}{|c|}{ Moderately important } & \multicolumn{3}{|c|}{ Very important } & \multicolumn{3}{|c|}{ Not applicable } \\
\hline & ISA & IG & Total & ISA & IG & Total & ISA & IG & Total & ISA & IG & Total & ISA & IG & Total \\
\hline Laptop & $\begin{array}{l}7 \\
(14)\end{array}$ & $\begin{array}{l}0 \\
(0 \%\end{array}$ & $\begin{array}{l}7 \\
(6 \%)\end{array}$ & $\begin{array}{l}1 \\
(2 \%)\end{array}$ & $\begin{array}{l}2 \\
(3 \%)\end{array}$ & $\begin{array}{l}3 \\
(2 \%)\end{array}$ & $\begin{array}{l}6 \\
(12 \%)\end{array}$ & $\begin{array}{l}1 \\
(1 \%)\end{array}$ & $\begin{array}{l}7 \\
(6 \%)\end{array}$ & $\begin{array}{l}37 \\
(73 \%)\end{array}$ & $\begin{array}{l}67 \\
(96 \%)\end{array}$ & $\begin{array}{l}104 \\
(86 \%)\end{array}$ & $\begin{array}{l}0 \\
(0 \%)\end{array}$ & $\begin{array}{l}0 \\
(0 \%)\end{array}$ & $\begin{array}{l}0 \\
(0 \%)\end{array}$ \\
\hline $\begin{array}{l}\text { Tablet or } \\
\text { iPad }\end{array}$ & $\begin{array}{l}21 \\
(41 \%)\end{array}$ & $\begin{array}{l}5 \\
(70\end{array}$ & $\begin{array}{l}26 \\
(21 \%)\end{array}$ & $\begin{array}{c}9 \\
(18 \%)\end{array}$ & $\begin{array}{c}7 \\
(10 \%)\end{array}$ & $\begin{array}{l}16 \\
(13 \%)\end{array}$ & $\begin{array}{l}7 \\
(14 \%)\end{array}$ & $\begin{array}{l}23 \\
(33 \%\end{array}$ & $\begin{array}{l}30 \\
(25 \%)\end{array}$ & $\begin{array}{l}4 \\
(8 \%)\end{array}$ & $\begin{array}{l}14 \\
(20 \%)\end{array}$ & $\begin{array}{l}18 \\
(15 \%)\end{array}$ & $\begin{array}{l}10 \\
(20 \%)\end{array}$ & $\begin{array}{l}21 \\
(30 \%)\end{array}$ & $\begin{array}{l}31 \\
(26 \%)\end{array}$ \\
\hline nartphone & $\begin{array}{l}11 \\
(22 \%)\end{array}$ & $\begin{array}{l}0 \\
(0 \%\end{array}$ & $\begin{array}{l}11 \\
(9 \%)\end{array}$ & $\begin{array}{l}10 \\
(20 \%)\end{array}$ & $\begin{array}{l}6 \\
(9 \%)\end{array}$ & $\begin{array}{l}16 \\
(13 \%)\end{array}$ & $\begin{array}{l}16 \\
(31 \%)\end{array}$ & $\begin{array}{l}21 \\
(30 \%\end{array}$ & $\begin{array}{l}37 \\
(31 \%)\end{array}$ & $\begin{array}{l}14 \\
(27 \%)\end{array}$ & $\begin{array}{l}43 \\
(61 \%)\end{array}$ & $\begin{array}{l}57 \\
(47 \%)\end{array}$ & $\begin{array}{c}0 \\
(0 \%)\end{array}$ & $\begin{array}{l}0 \\
(0 \%)\end{array}$ & $\begin{array}{l}0 \\
(0 \%)\end{array}$ \\
\hline E-reader & $\begin{array}{l}22 \\
(43 \%)\end{array}$ & 4 & $\begin{array}{l}26 \\
(21 \%)\end{array}$ & 7 & $\begin{array}{l}10 \\
(14 \%)\end{array}$ & $\begin{array}{l}17 \\
(14 \%)\end{array}$ & $\begin{array}{l}3 \\
(6 \%)\end{array}$ & $\begin{array}{l}18 \\
(26 \%\end{array}$ & $\begin{array}{l}21 \\
(17 \%)\end{array}$ & $\begin{array}{l}4 \\
(8 \%)\end{array}$ & $\begin{array}{l}8 \\
(11 \%)\end{array}$ & $\begin{array}{l}12 \\
(10 \%)\end{array}$ & $\begin{array}{l}15 \\
(29 \%)\end{array}$ & $\begin{array}{l}30 \\
(43 \%)\end{array}$ & $\begin{array}{l}45 \\
(37 \%)\end{array}$ \\
\hline
\end{tabular}

Number of participants: $I S A=51 ;$ IG $=70 ;$ Total=121

In Table 3, more students rated Laptop as a very important device towards their academic success than the other devices. Furthermore, Smartphone is important towards the academic success of $\mathbf{9 4}(\mathbf{7 8 \%} \%$ ) of the participants. Importance of Tablet or iPad and Ereader towards participants' academic success is marginal.

Students have argued that using the Laptop and Smartphone helps their research work since the Internet contributes to their academic success. "I am very comfortable whenever I have my phone or laptop with me and it is connected. It makes me confident" (ISA Participant). Design students again find need for the use of laptops for their practicals. Another participant also said that "I run a lot of software [sic] on my computer that allows me to produce my artifacts"(ISA Participant). Technology has simply modified every aspect of our educational systems including our cultural and belief systems (Nilson \& Weaver, 2005) "These days, it is difficult getting people for studio art...People no longer want to pose naked to be drawn... with 3D programs, it is easier, neater beautiful to communicate a message through art" (IG Participant). Ownership of Laptops and Smartphones are very vital to the success of students' academic work. Like the rhizome that has no center and structuralized connection, these devices used by students are used to connect to people and resources at different levels and for different purposes.

As indicated in Table 3, students value handheld mobile devices that promote communication with other students about class related matters outside class sessions because, it creates a much more convenient learning environment for them. This finding supports students' inclination towards technology integration in their learning (Boyd, 2014; Goode, 2010).

\section{Survey question 4}

How are handheld mobile devices important to ISA and IG design students towards academic success? 
Table 4. Importance of handheld mobile devices to academic success

\begin{tabular}{|c|c|c|c|c|c|c|c|c|c|c|c|c|c|c|}
\hline \multirow[b]{2}{*}{ Item } & \multicolumn{3}{|c|}{$\begin{array}{c}\text { Not at all } \\
\text { important }\end{array}$} & \multicolumn{3}{|c|}{ Not very important } & \multicolumn{3}{|c|}{$\begin{array}{c}\text { Moderately } \\
\text { important }\end{array}$} & \multicolumn{3}{|c|}{$\begin{array}{c}\text { Very } \\
\text { important }\end{array}$} & \multirow[b]{2}{*}{ Mean } & \multirow[b]{2}{*}{ Ranl } \\
\hline & ISA & IG & Total & ISA & IG & Total & ISA & IG & Total & ISA & IG & Total & & \\
\hline $\begin{array}{l}\text { Access library } \\
\text { resources }\end{array}$ & $\begin{array}{l}11 \\
(22 \%) \\
\end{array}$ & $\begin{array}{l}4 \\
(6 \%) \\
\end{array}$ & $\begin{array}{l}15 \\
(12 \%)\end{array}$ & $\begin{array}{l}12 \\
(24 \%)\end{array}$ & $\begin{array}{l}11 \\
(16 \%)\end{array}$ & $\begin{array}{l}23 \\
(19 \%)\end{array}$ & $\begin{array}{l}19 \\
(37 \%)\end{array}$ & $\begin{array}{l}20 \\
(29 \%)\end{array}$ & $\begin{array}{l}39 \\
(32 \%)\end{array}$ & $\begin{array}{l}9 \\
(18 \%)\end{array}$ & $\begin{array}{l}35 \\
(50 \%) \\
\end{array}$ & $\begin{array}{l}44 \\
(36 \%)\end{array}$ & 2.93 & $10^{\text {th }}$ \\
\hline Check grades & $\begin{array}{l}5 \\
(10 \%) \\
\end{array}$ & $\begin{array}{l}2 \\
(3 \%) \\
\end{array}$ & $\begin{array}{l}7 \\
(6 \%) \\
\end{array}$ & $\begin{array}{l}7 \\
(14 \% \\
\end{array}$ & \begin{tabular}{l|}
6 \\
$(9 \%)$ \\
\end{tabular} & \begin{tabular}{l|l}
13 \\
$(11 \%)$
\end{tabular} & \begin{tabular}{l|l}
15 \\
$(29 \%)$ \\
\end{tabular} & $\begin{array}{l}12 \\
(17 \%)\end{array}$ & \begin{tabular}{l|l}
27 \\
$(22 \%)$
\end{tabular} & $\begin{array}{l}24 \\
(47 \%)\end{array}$ & $\begin{array}{l}50 \\
(71 \%) \\
\end{array}$ & $\begin{array}{l}74 \\
(61 \%)\end{array}$ & 3.39 & $3^{\text {rd }}$ \\
\hline $\begin{array}{l}\text { Register for } \\
\text { courses }\end{array}$ & $\begin{array}{l}12 \\
(24 \%) \\
\end{array}$ & $\begin{array}{l}5 \\
(7 \%) \\
\end{array}$ & $\begin{array}{l}17 \\
(14 \%) \\
\end{array}$ & $\begin{array}{l}5 \\
(10 \%) \\
\end{array}$ & $\begin{array}{l}16 \\
(23 \%) \\
\end{array}$ & $\begin{array}{l}21 \\
(17 \%) \\
\end{array}$ & $\begin{array}{l}8 \\
(16 \%) \\
\end{array}$ & $\begin{array}{l}21 \\
(30 \%)\end{array}$ & $\begin{array}{l}29 \\
(24 \%) \\
\end{array}$ & $\begin{array}{l}26 \\
(51 \%)\end{array}$ & $\begin{array}{l}28 \\
(40 \%) \\
\end{array}$ & $\begin{array}{l}54 \\
(45 \%) \\
\end{array}$ & 2.99 & $8^{\text {th }}$ \\
\hline $\begin{array}{l}\text { Use the course or } \\
\text { learning } \\
\text { management } \\
\text { system (e.g., } \\
\text { Blackboard, } \\
\text { Moodle, Sakai, } \\
\text { etc.) }\end{array}$ & $\begin{array}{l}14 \\
(27 \%)\end{array}$ & $\begin{array}{l}10 \\
(14 \%)\end{array}$ & $\begin{array}{l}24 \\
(20 \%)\end{array}$ & $\begin{array}{l}8 \\
(16 \%)\end{array}$ & $\begin{array}{l}22 \\
(31 \%)\end{array}$ & $\begin{array}{l}30 \\
(25 \%)\end{array}$ & $\begin{array}{l}19 \\
(37 \%)\end{array}$ & $\begin{array}{l}28 \\
(40 \%)\end{array}$ & $\begin{array}{l}47 \\
(39 \%)\end{array}$ & $\begin{array}{l}10 \\
(20 \%)\end{array}$ & $\begin{array}{l}10 \\
(14 \%)\end{array}$ & $\begin{array}{l}20 \\
(17 \%)\end{array}$ & 2.52 & $12^{\text {th }}$ \\
\hline $\begin{array}{l}\text { Access } \\
\text { information } \\
\text { about events, } \\
\text { student } \\
\text { activities, and } \\
\text { clubs/organisati } \\
\text { ons }\end{array}$ & $\begin{array}{l}9 \\
(18 \%)\end{array}$ & $\begin{array}{l}0 \\
(0 \%) \\
\end{array}$ & $\begin{array}{l}9 \\
(7 \%)\end{array}$ & $\begin{array}{l}12 \\
(24 \%)\end{array}$ & $\begin{array}{l}4 \\
(6 \%) \\
\end{array}$ & $\begin{array}{l}16 \\
(13 \%)\end{array}$ & $\begin{array}{l}15 \\
(29 \%) \\
\end{array}$ & $\begin{array}{l}27 \\
(39 \%)\end{array}$ & $\begin{array}{l}42 \\
(35 \%)\end{array}$ & $\begin{array}{l}15 \\
(29 \%)\end{array}$ & $\begin{array}{l}39 \\
(56 \%) \\
\end{array}$ & $\begin{array}{l}54 \\
(45 \%)\end{array}$ & 3.17 & $5^{\text {th }}$ \\
\hline Read e-texts & $\begin{array}{l}12 \\
(24 \%)\end{array}$ & $\begin{array}{l}3 \\
(4 \%) \\
\end{array}$ & $\begin{array}{l}15 \\
(12 \%) \\
\end{array}$ & $\begin{array}{l}15 \\
(29 \%) \\
\end{array}$ & $\begin{array}{l}4 \\
(6 \%) \\
\end{array}$ & $\begin{array}{l}19 \\
(16 \% \\
\end{array}$ & $\begin{array}{l}14 \\
(27 \%)\end{array}$ & $\begin{array}{l}23 \\
(33 \%)\end{array}$ & $\begin{array}{l}37 \\
(31 \%)\end{array}$ & $\begin{array}{l}10 \\
(20 \%)\end{array}$ & $\begin{array}{l}40 \\
(57 \%)\end{array}$ & $\begin{array}{l}50 \\
(41 \%)\end{array}$ & 3.01 & $7^{\text {th }}$ \\
\hline $\begin{array}{l}\text { Communicate } \\
\text { with other } \\
\text { students about } \\
\text { class related } \\
\text { matters outside } \\
\text { class }\end{array}$ & $\begin{array}{l}4 \\
(8 \%) \\
\end{array}$ & $\begin{array}{l}0 \\
(0 \%)\end{array}$ & $\begin{array}{l}4 \\
(3 \%) \\
\end{array}$ & $0(0 \%)$ & $\begin{array}{l}1 \\
(1 \%)\end{array}$ & $\begin{array}{l}1 \\
(1 \%)\end{array}$ & $\begin{array}{l}14 \\
(27 \%)\end{array}$ & $\begin{array}{l}9 \\
(13 \%)\end{array}$ & $\begin{array}{l}23 \\
(19 \%)\end{array}$ & $\begin{array}{l}33 \\
(65 \%)\end{array}$ & $\begin{array}{l}60 \\
(86 \%) \\
\end{array}$ & $\begin{array}{l}93 \\
(77 \%)\end{array}$ & 3.69 & $1^{\text {st }}$ \\
\hline $\begin{array}{l}\text { Look up } \\
\text { information } \\
\text { while in class }\end{array}$ & $\begin{array}{l}4 \\
(8 \%) \\
\end{array}$ & $\begin{array}{l}0 \\
(0 \%)\end{array}$ & $\begin{array}{l}4 \\
(3 \%) \\
\end{array}$ & $\begin{array}{l}8 \\
(16 \%)\end{array}$ & $\begin{array}{l}7 \\
(10 \%)\end{array}$ & $\begin{array}{l}15 \\
(12 \%)\end{array}$ & $\begin{array}{l}10 \\
(20 \%)\end{array}$ & $\begin{array}{l}15 \\
(21 \%)\end{array}$ & $\begin{array}{l}25 \\
(21 \%)\end{array}$ & $\begin{array}{l}29 \\
(57 \%)\end{array}$ & $\begin{array}{l}48 \\
(69 \%)\end{array}$ & $\begin{array}{l}77 \\
(64 \%)\end{array}$ & 3.45 & $2^{\text {nd }}$ \\
\hline $\begin{array}{l}\text { Capture static } \\
\text { images of in- } \\
\text { class activities or } \\
\text { resources }\end{array}$ & $\begin{array}{l}4 \\
(8 \%)\end{array}$ & $\begin{array}{l}2 \\
(3 \%)\end{array}$ & $\begin{array}{l}6 \\
(5 \%)\end{array}$ & $\begin{array}{l}7 \\
(14 \%)\end{array}$ & $\begin{array}{l}8 \\
(11 \%)\end{array}$ & $\begin{array}{l}15 \\
(12 \%)\end{array}$ & $\begin{array}{l}10 \\
(20 \%)\end{array}$ & $\begin{array}{l}28 \\
(40 \%)\end{array}$ & $\begin{array}{l}38 \\
(31 \%)\end{array}$ & $\begin{array}{l}30 \\
(59 \%)\end{array}$ & $\begin{array}{l}32 \\
(46 \%)\end{array}$ & $\begin{array}{l}62 \\
(51 \%)\end{array}$ & 3.29 & $4^{\text {th }}$ \\
\hline $\begin{array}{l}\text { Record your } \\
\text { instructor's } \\
\text { lecture or in- } \\
\text { class activities } \\
\text { (audio, visual, or } \\
\text { both) }\end{array}$ & $\begin{array}{l}7 \\
(14 \%)\end{array}$ & $\begin{array}{l}6 \\
(9 \%)\end{array}$ & $\begin{array}{l}13 \\
(11 \%)\end{array}$ & $11(22 \%)$ & $\begin{array}{l}21 \\
(30 \%)\end{array}$ & $\begin{array}{l}32 \\
(26 \%)\end{array}$ & $\begin{array}{l}16 \\
(31 \%)\end{array}$ & $\begin{array}{l}22 \\
(31 \%)\end{array}$ & $\begin{array}{l}38 \\
(31 \%)\end{array}$ & $\begin{array}{l}17 \\
(33 \%)\end{array}$ & $\begin{array}{l}21 \\
(30 \%)\end{array}$ & $\begin{array}{l}38 \\
(31 \%)\end{array}$ & 2.83 & $11^{\text {th }}$ \\
\hline $\begin{array}{l}\text { Participate in } \\
\text { interactive class } \\
\text { activities }\end{array}$ & $\begin{array}{l}8 \\
(16 \%)\end{array}$ & $\begin{array}{l}2 \\
(3 \%)\end{array}$ & $\begin{array}{l}10 \\
(8 \%)\end{array}$ & $\begin{array}{l}12 \\
(24 \%)\end{array}$ & $\begin{array}{l}9 \\
(13 \%)\end{array}$ & $\begin{array}{l}21 \\
(17 \%)\end{array}$ & $\begin{array}{l}17 \\
(33 \%)\end{array}$ & $\begin{array}{l}25 \\
(36 \%)\end{array}$ & $\begin{array}{l}42 \\
(35 \%)\end{array}$ & $\begin{array}{l}14 \\
(27 \%)\end{array}$ & $\begin{array}{l}34 \\
(49 \%)\end{array}$ & $\begin{array}{l}48 \\
(40 \%)\end{array}$ & 3.06 & $6^{\text {th }}$ \\
\hline $\begin{array}{l}\text { Use the mobile } \\
\text { device as a } \\
\text { digital passport } \\
\text { for access or } \\
\text { identification }\end{array}$ & $\begin{array}{l}12 \\
(24 \%)\end{array}$ & $\begin{array}{l}5 \\
(7 \%)\end{array}$ & $\begin{array}{l}17 \\
(14 \%)\end{array}$ & $\begin{array}{l}9 \\
(18 \%)\end{array}$ & $\begin{array}{l}12 \\
(17 \%)\end{array}$ & $\begin{array}{l}21 \\
(17 \%)\end{array}$ & $\begin{array}{l}15 \\
(29 \%)\end{array}$ & $\begin{array}{l}20 \\
(29 \%)\end{array}$ & $\begin{array}{l}35 \\
(29 \%)\end{array}$ & $\begin{array}{l}15 \\
(29 \%)\end{array}$ & $\begin{array}{l}33 \\
(47 \%)\end{array}$ & $\begin{array}{l}48 \\
(40 \%)\end{array}$ & 2.94 & $9^{\text {th }}$ \\
\hline
\end{tabular}

On the whole, Table 4 shows that participants use handheld mobile devices to communicate among themselves about class related matters outside class sessions $(M=3.69)$ was ranked $1^{\text {st }}$. Participants ranked $2^{\text {nd }}$ the use of handheld mobile devices to look up information while in class $(M=3.45)$. Checking of grades $(M=3.39)$ and the Capturing of static images of inclass activities or resources $(M=3.29)$ were ranked $3^{\text {rd }}$ and $4^{\text {th }}$ respectively. Though moderately important, Accessing library resources $(M=2.93)$, Recording instructors' lecture or in-class activities $(M=2.83)$ and the Use of course or learning management system $(M=2.52)$ were ranked as the last three in terms of the uses of handheld mobile devices for academic success. 


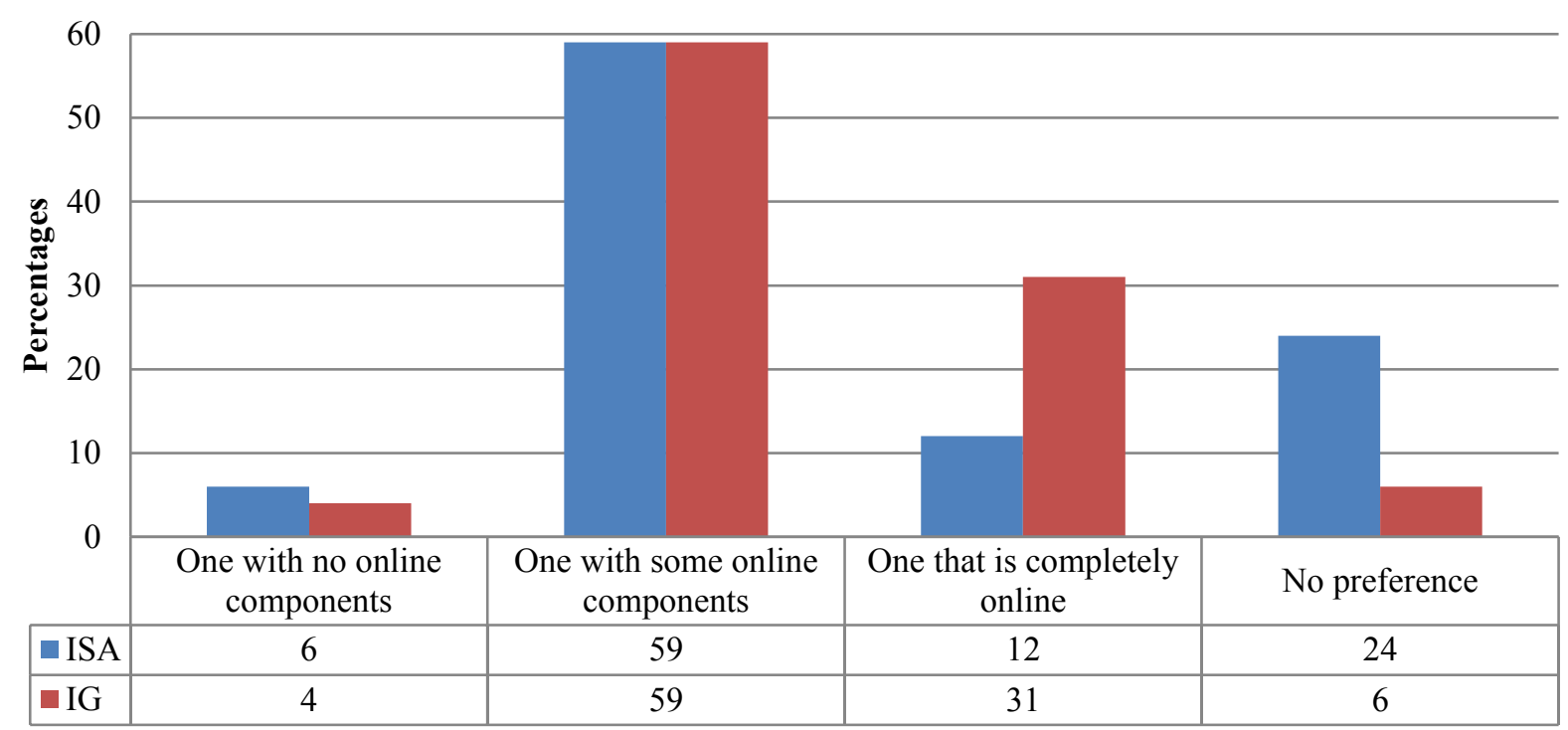

Figure 2. Preferred learning environments of design students

Despite the proliferation of online technologies, $59 \%$ of the participants prefer a learning environment that is blended. This may come on the backdrop that some of their lecturers still train them through the traditional mode of delivery while they on their own accord, explore to use media technologies to translate the traditional mode to the digital or online mode. According to a participant, "it is not prudent to put your whole life online. In this era of load shedding, one must be versatile in the use of traditional and offline platforms too" (IG Participant). Those students who prefer completely online learning environments may have been trained that way for a very long time since their infancy.

It is valuable noting that there is statistically significant difference between the learning environment preference of ISA and IG design students. This may be as a result of both environmental and pedagogical reasons that need further research. These reasons range from the processes of admission into such programs. In ISA, one does not need any basic formal qualification in Design at high school level while in IG, it is a requirement to pass some elective courses such as General Knowledge in Arts and at least one other course in Visual Arts to qualify you admission into a bachelor's course in Design.

Null Hypothesis 1

There is no statistically significant difference between the two institutions' design students in terms of learning environment preferences.

Table 5. Comparison of learning environment preferences by institution

\begin{tabular}{llllcllll}
\hline $\begin{array}{l}\text { Preferred } \\
\text { environment }\end{array}$ & learning & Institution & N & Mean & $\begin{array}{l}\text { Std. } \\
\text { Dev. }\end{array}$ & $\begin{array}{l}\text { t- } \\
\text { value }\end{array}$ & df & Sig \\
\cline { 2 - 6 } & ISA & 51 & 2.53 & .946 & -3.667 & 119 & .000 \\
\cline { 2 - 6 } & IG & 70 & 3.10 & .764 & \\
\hline
\end{tabular}

In Table 5, the mean score of preferred learning environment by design students ISA ( $M=2.53, S D=.946$ ) was statistically significant different from the learning environment of design students IG $(M=3.10, S D=.764) ; t(121)=-3.667, p<.05, C_{95}-.879,-262$. Therefore, we reject the null hypothesis that there is no statistically significant difference between ISA and IG design students in terms of learning environments preferences. The differences may be as a result of the Laptop policies in place in the two institutions. It may also be as a result of the admission requirements that exist in both institutions. While a course in design at the high school is no prerequisite for prospective students in ISA, it is mandatory to have passes in at least two design related courses for consideration of admission in IG. 
The different entry requirements in both institutions may be attributed in the results in Table 5. This means that students admitted to read Design in ISA may have very short time, may be months to decide to do so whereas, in IG, students would have practiced and have the idea of basic terminologies in Design long before admission. The Internet bandwidth may also not be an issue for both categories of students. Though students are unhappy about Internet services in their institutions, as much as possible, students provide their own Internet to supplement what the universities offer them. The Learning Management Systems may also not be a favorable platform for such students. According to an ISA participant, the institutional Internet nor Learning Management System did not support design education. "...this Internet is so slow and blackboard will never work for design students. We have to be thinking about appropriate Leaning Management Systems for design students because blackboard is not for us."

\section{Null Hypothesis 2}

There is no statistically significant difference between the two institutions' design students in the use of handheld mobile devices to enhance academic work.

Table 6. Comparison of gender influence of design students and their learning environment preferences

\begin{tabular}{|c|c|c|c|c|c|c|c|c|}
\hline \multirow{3}{*}{$\begin{array}{l}\text { Preferred } \\
\text { environment }\end{array}$} & \multirow{3}{*}{ learning } & Gender & $\mathbf{N}$ & Mean & $\begin{array}{l}\text { Std. } \\
\text { Dev. }\end{array}$ & $\begin{array}{l}\text { t- } \\
\text { value }\end{array}$ & df & Sig \\
\hline & & Male & 54 & 2.89 & .945 & \multirow{2}{*}{.326} & \multirow{2}{*}{119} & \multirow{2}{*}{.056} \\
\hline & & Female & 67 & 2.84 & .846 & & & \\
\hline
\end{tabular}

On learning environment preferences of design students and their gender, the mean score indicated that there was no statistically significant difference between Male $(M=2.89$, $S D=.945)$ and Female $(M=2.84, S D=846) ; t(121)=.326, p>.05, C l .95-.270,-376$. Therefore, we fail to reject the null hypothesis that there is no statistically significant difference between male and female design students in terms of learning environment preferences. The learning environment preferences between male and female present no differences, according to Table 6. Design students irrespective of gender perceive a common learning environment towards success in their academic work. Gender, in most cases influence decisions made in academia. This shows gender representation does not play a major role in a digitally mediated world. Students cope with mediating tools irrespective of their gender and preferred learning environments rather than their gender representation (Boyd, 2014; Warburton, 2010). The results in Table 6 have implications on curriculum development for design.

\section{Null Hypothesis 3}

There is no statistically significant difference between the two institutions' design students in the use of handheld mobile devices to enhance academic work.

Table 7. Comparison of design students and their use of handheld mobile devices for academic success by institution

\begin{tabular}{llllllll}
\hline & Institution & N & Mean & $\begin{array}{l}\text { Std. } \\
\text { Dev. }\end{array}$ & $\begin{array}{l}\text { t- } \\
\text { value }\end{array}$ & df & Sig \\
\cline { 2 - 8 } & ISA & 51 & 3.33 & .683 & -3.523 & 119 & .001 \\
\hline
\end{tabular}

The mean score for use of handheld mobile devices to enhance academic success by ISA ( $M=3.33, S D=.683$ ) was statistically significant different from IG $(M=3.70, S D=.462)$; $t(121)=-3.523, p<.05, C l .95-.573,-161$. Therefore, we reject the null hypothesis that there is no statistically significant difference between ISA and IG design students in the use of handheld mobile devices to enhance academic success. The differences in the use of handheld devices can be accounted for by the differences in their device ownership and 
uses. It is not surprising that Table 7 reveals that IG Design students use of handheld mobile devices for academic success is more than their counterparts in ISA (3.70>3.33). This is so because, results in Figure 1 show an average number of IG participants who own and use mobile handheld devices in comparison to ISA participants. Again, Figure 1 clearly points that more IG participants own Smartphones than their ISA counterparts.

\section{CONCLUSIONS}

In summary, the study sought to explore device ownership, use and the configuration of learning environment preferences of design students in ISA and IG (South Africa and Ghana, respectively). This study was in response to Barry et al.'s (2015, p. 209) recommendation for continuous need to pay attention to how socio- technological advances affect teaching and learning among students. Design students in the two institutions own, utilize and rate Laptop and Smartphone as very important tools for their academic engagement. Furthermore, the students generally prefer blended learning environment followed online learning environment. The study revealed no statistically significant difference in learning environment preference and gender of design students.

Design students in the institutions own and use various devices to promote their learning. Device ownership influences the way students learn and connect with their learning environment. The majority of students own Smartphones and Laptops. From the data, these basic tools of communication support learning (Table 2), however, the study established statistically significant difference between the two institutions' design students in the use of handheld mobile devices to enhance their academic work.

Design students use Smartphones a lot, but they do not use Tablets as much as they use Laptops and Smartphones. Smartphones have small screens, and library portals usually provide a lot of information. Using library portals from Smartphones is probably not the best navigation experience one can have in a Smartphone. Googling, on the other hand, is pretty easy form for a Smartphone. Students' look-up information while in class much more frequently than they access library or LMS probably, because, the library and LMS interfaces are heavy and not suitable to small screens. Findings on lookup contravene results found by Motiwalla (2015) where students had challenges look up due to application interface. Nonetheless, Motiwalla's (2015) findings strongly support reasons why the students did not rank high "Access library resources." A more interactive or improved library portal interface with additional features may increase the patronage of use. The later can be supported by McKnight's, (2011, p. 4) arguments on the need to "place greater emphasis on rendering library digital content" for better access and use on digital devices.

Checking of grades on handheld devices is high and may be attributed to the students' expectations of quick feedback on their academic performances. Again, navigating a Smartphone to check grades may be less complicated as compared to libraries and LMS. It is possible that the institutions' expectations, and investments, are higher in library resources, LMS development and faculty training that are bottom ranked. Perhaps, due to institutional policies, the institutions and lecturers probably do not put much effort to make lecture rooms a 'nice stage' to students capture still images from in-class activities that is well ranked. Looking at the various preferred learning environments for students, they are able to quickly adapt to what the institutions provide them based on the expectations of the institution. This is evident in the responses in Table 4. Nonetheless, this adaptation may have some consequences to creativity which underpins creativity and technology transfer.

\section{RECOMMENDATIONS}

It is recommended that Learning Environments for Design Education by UoTs viz-a-viz institutional device ownership policies be revisited. A blended learning environment is 
recommended because: 1 . The majority of design students prefer and are inclined towards blended learning environments. 2. Device ownership among design students is reasonably large and the fact that UoTs strive to promote teaching and learning via different technological perspectives. 3. Further research into the suitability of blended learning environment for design education can be explored for its potentials.

Further research needs to be conducted on why there were statistically significant differences between ISA and IG design students in the use of handheld mobile devices to enhance academic success. Fundamental courses in design as a pre-requisite for admission in UoTs must be re-examined since it impacts greatly on performance and commitment of design students. It is finally recommended that a blended approach in designing learning environments for design education is worthwhile and must be considered by curriculum developers. The re-examination will help bring some creativity in the delivery methods of the courses leveraging on students' inclination to blended forms of delivery and learning.

\section{BIODATA and CONTACT ADDRESSES of AUTHORS}

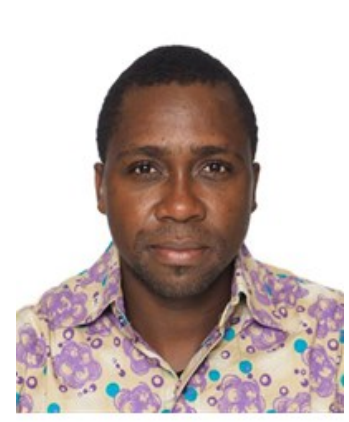

Dr. Simon-Peter Kafui AHETO is a Lecturer of Educational \& Information Technology at the Department of Mathematics and ICT Education, Faculty of Science and Technology Education, College of Education, University of Cape Coast. He holds a Doctor of Technology (Information Technology) from the Cape Peninsula University of Technology in Cape Town, South Africa. His academic interest areas are rhizomatic learning, learning analytics, social network analysis, open and distance learning, entrepreneurship education and youth development. He has over 12 journal and conference articles published in international indexes, a book, an international book chapter, technical reports, and papers submitted to international meetings.

\section{Dr. Simon-Peter Kafui AHETO}

Department of Mathematics and ICT Education, Faculty of Science and Technology Education,

College of Education, University of Cape Coast

Cape Coast Ghana

Phone: + 233244222904

E-mail: kafuiaheto@yahoo.com or saheto@ucc.edu

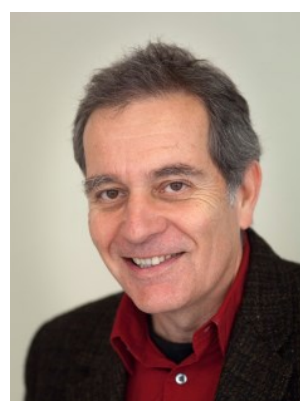

Johannes CRONJE is a Professor of Computers in Education and Dean of the Faculty of Informatics and Design at the Cape Peninsula University of Technology in Cape Town, South Africa. He obtained a Doctorate in Afrikaans Literature in 1990 and then a Masters Degree in Computer-Assisted Education from the University of Pretoria, South Africa. His academic interest areas are rhizomatic learning, computers in education, e-learning and Instructional Design. He has supervised or co-supervised 72 Masters and 55 Doctoral students and published more than 42 research papers.

Professor Johannes CRONJE

Faculty of Informatics and Design

Cape Peninsula University of Technology

Cape Town, South Africa

Phone: +27825585311

E-mail: johannes.cronje@gmail.com or cronjej@cput.ac.za 


\section{REFERENCES}

Aheto, S-P. K., \& Cronje, J. C. (2014). A rhizoanalysis of learning connections among higher education learners. In R. de la Harpe, S. Warden \& E. Appiah (Eds.). Proceedings of the $4^{\text {th }}$ International Conference on Design, Development \& Research (pp. 439-457). Cape Town, South Africa: Faculty of Informatics, Cape Peninsula University of Technology.

Airtel (2013, October 24). Airtel partners with wikimedia foundation to bring free access to wikipedia to 70 million people in 17 countries. Retrieved February 23, 2015, from http://africa.airtel.com/wps/wcm/connect/africarevamp/ africa/home/media/press-releases/october-24-2013

Ally, M. (2009). Mobile learning: Transforming the delivery of education and training. Edmonton: Athabasca University Press.

Appiah, E. (2014). An exploration of ICT for graphic design education at a public university: issues of ideation and pedagogy (Doctoral Dissertation). Cape Peninsula University of Technology, Cape Town, South Africa.

Baddeley, A. (2012, May 27). Ebooks: Winners in the generation game. The Guardian. United Kingdom. Retrieved April 15, 2016, from http://www.theguardian.com/ books/2012/may/27/ebooks-growth-older-age-groups

Barry, S., Murphy, K., \& Drew, S. (2015). From deconstructive misalignment to constructive alignment: Exploring student uses of mobile technologies in university classrooms. Computers \& Education, 81, 202-210.

Baynes, K. (2010). Models of Change: The future of design education. Design and Technology Education: an International Journal, 15(3), 10-17.

Billings, H. (2003). The Wild-Card Academic Library in 2013. College \& Research Libraries, 64 (2), 105-109.

Bita, N. (2016, March 26). Computers in class 'a scandalous waste': Sydney Grammar head. Retrieved March 30, 2016, from http://www.theaustralian.com.au/ nationalaffairs/education/computers-in-class-a-scandalous-waste-sydney-grammarhead/news-story/b6de07e63157c98db9974cedd6daa503

Boyd, D. (2014). It's complicated: The social lives of networked teens. Yale University Press.

Bozanta, A., \& Mardikyan, S. (2017). The Effects of Social Media Use on Collaborative Learning: A Case of Turkey. Turkish Online Journal of Distance Education, $18(1), 96-110$.

Brook, D. (2000). 'The making of a university of technology'. In Lategan, L.O.K. (Eds.). Studies in Higher Education: Bloemfontein.

Brown, M. (2009). The NetGens 2.0: Clouds on the horizon, EduCause Review, 44(1), 66-67.

Caruso, J. B., \& Salaway, G. (2008). The ECAR Study of Undergraduate Students and Information Technology, 2008. ECAR Research Studies Colorado: EDUCAUSE Center for Applied Research.

Cross, S., Sharples, M., \& Healing, G. (2015). E-Pedagogy of Handheld Devices 2013 Survey: Patterns of student use for learning (Research and Innovation Report). Milton Keynes, UK: The Open University.

Cummings, J., Merrill, A., \& Borrelli, S. (2010). The use of handheld mobile devices: their impact and implications for library services. Library Hi Tech, 28(1), 22-40.

Dahlstrom, E. de Boor, T., Grunwald, P., \& Vockley, M. (2011). ECAR: National Study of Undergraduate Students and Information Technology, 2011 (Research Report). Boulder, CO: EDUCAUSE Center for Applied Research.

Eden, D., \& Bichsel, J. (2014). ECAR Study of Undergraduate Students and Information Technology, 2014 (Research Report). Louisville, CO: EDUCAUSE Center for Applied Research. 
Eton, S. E. (2011). Literacy, Languages and Leadership 21 Characteristics of 21st Century Learners. Retrieved June 4, 2014, from http://drsaraheaton.wordpress.com/2011/12/07/21st-century-learners/

Evans, C. (2008). The effectiveness of $m$-learning in the form of podcast revision lectures in higher education. Computers \& Education, 50, 491-498.

Falloon, G. (2015). What's the difference? Learning collaboratively using iPads in conventional classrooms. Computers \& Education, 84, 62-77.

Farrant, J.S. (1980). Principles and Practice of Education New Edition. Hong Kong: Longman.

Gaskell, A. (2015). Can we really learn from mobile handheld devices? Retrieved April 20, 2016, from http://pcfpapers.colfinder.org/bitstream/handle/123456789/ 428/2010_GaskellA_Mobile_devices.pdf?sequence $=1$ 18isAllowed $=y$

Gikas, J., \& Grant, M. M. (2013). Mobile computing devices in higher education: Student perspectives on learning with cellphones, smartphones \& social media. The Internet and Higher Education, 19, 18-26.

Goode, J. (2010). The digital identity divide: how technology knowledge impacts college students. New media \& society, 12(3), 497-513.

Gupta, B., \& Koo, Y. (2010). Applications of mobile learning in higher education: An empirical study. International Journal of Information and Communication Technology Education, 6(3), 75-87.

Hamblen, M. (2011, May 19). Amazon: E-books now outsell print books. Computerworld. Retrieved April 20, 2016, from http://www.computerworld.com/article/ 2508262/mobile-wireless/amazon--e-books-now-outsell-print-books.html

Herrington, J., Reeves, T. C., \& Oliver, R. (2010). A guide to authentic e-learning. NewYork: Routledge.

Hsu, J. (2007). Innovative technologies for education and learning: Education and knowledgeoriented applications of blogs, wikis, podcasts, and more. International Journal of Information and Communication Technology Education, 3(3), 70-89.

Huang, Y. M., Liao, Y. W., Huang, S. H., \& Chen, H. C. (2014). A Jigsaw based Cooperative Learning Approach to Improve Learning Outcomes for Mobile Situated Learning. Educational Technology \& Society, 17(1), 128-140.

Johnson, L., Adams Becker, S., Estrada, V., \& Freeman, A. (2014). NMC Horizon Report: 2014 Library Edition (Horizon Report). Austin, Texas. The New Media Consortium.

Karchmer- Klein, R., \& Shinas, V. H. (2012). Guiding principles for supporting new literacies in your classroom, The Reading Teacher, 65(5), 288-293.

Krejcie, R.V. \& Morgan, D.W. 1970. Determining sample size for research activities. Educational \& Psychological Measurement, 30: 607-610.

Kiesler, S. \& Sproull, L. 1987. Computing and Change on Campus. New York: Cambridge University Press.

Kong, S. C., Chan, T. W., Griffin, P., Hoppe, U., Huang, R., Kinshuk, Looi, C. K., Milrad, M., Norris, C., Nussbaum, M., Sharples, M., So, W. M. W., Soloway, E., \& Yu, S. (2014). Elearning in School Education in the Coming 10 Years for Developing 21st Century Skills: Critical Research Issues and Policy Implications. Educational Technology \& Society, 17(1), 70-78.

Koole, M., \& Stack, S. (2016). Doctoral students' identity positioning in networked learning environments. Distance Education, 3ᄌ(1), 41-59.

Krueger, R.A. 1986. Focus group interviewing: A helpful technique for agricultural educators. The Visitor, 73(7): 1-4.

Lai, C. L., \& Hwang, G. J. (2015). An interactive peer-assessment criteria development approach to improving students' art design performance using handheld devices. Computers \& Education, 85, 149-159. 
Lee, K. S., \& Kim, B. G. (2016). Cross Space: The Exploration of SNS-Based Writing Activities in a Multimodal Learning Environment. Educational Technology \& Society, 19(2), 57-76.

Leeson, H. V. (2006). The mode effect: A literature review of human and technological issues in computerized testing. International Journal of Testing, $6(1), 1-24$.

Lefever, S., Dal, M. \& Matthiasdottir, A. 2007. Online data collection in academic research: advantages and limitations. British Journal of Educational Technology, 38(4): 574582.

Leye, V. (2007). UNESCO, ICT corporations and the passion of ICT for development: modernization resurrected. Media, Culture \& Society, 29(6), 972-993.

Manzini, E. (2015). Design, when everybody designs: An introduction to design for social innovation. Cambridge, Massachusetts: The MIT Press.

McKnight, S. (2011). Here Today and Here Tomorrow. In P. Dale, J. Beard, M. Holland (Eds.), University Libraries and Digital Learning Environments (pp. 1-14). London: Ashgate.

Miller, J. R. (2016). Teaching Machines: Learning from the Intersection of Education and Technology by Bill Ferster (review). The Review of Higher Education, 39(2), 306-307.

Mitchell, V. (1996). Assessing the reliability and validity of questionnaires: an empirical example. Journal of Applied Management Studies, 5, 199-208.

Motiwalla, L. F. (2007). Mobile learning: A framework and evaluation, Computers \& Education, 49, 581-596.

MTN Ghana. (n.d.). MTN Ghana Empowers Customers With Free Access To Wikipedia. Retrieved February 23, 2015, from http://mtn.com.gh/about-mtn/press/mtn-ghanaempowers-customers-with-free-access-to-wikipedia

Muianga, Xavier; Hansson, Henrik; Nilsson, Anders; Mondlane, Avelino; Mutimucuio, Inocente; and Guambe, Alsone (2013) "ICT in Education in Africa - Myth or Reality: A Case Study of Mozambican Higher Education Institutions". The African Journal of Information Systems, 5(3), 106-117

Munshi, K. (2010). Characteristics of Design and its implications on Design Education. Retrieved April 10, 2016, from http://www.idc.iitb.ac.in/munshi/ CHARACTERISTICS\%200F\%20DESIGN\%20AND\%20ITS\%20IMPLICATIONS\%200N $\% 20 D E S I G N \% 20 \% 20 E D U C A T I O N . p d f$

Nilson, L., \& Weaver, B. E. (2005). Enhancing Learning with Laptops in the Classroom: New Directions for Teaching and Learning, Number 101. Wiley.

Oliver, M. (2011). Technological determinism in educational technology research: some alternative ways of thinking about the relationship between learning and technology. Journal of Computer Assisted Learning, 2オ(5), 373-384.

Paliktzoglou, V., \& Suhonen, J. (2014). Microblogging in Higher Education: The Edmodo Case Study among Computer Science Learners in Finland. Journal of Cases on Information Technology, 16(2), 39-57.

Plowright, D. 2011. Using mixed methods: Frameworks for an integrated methodology. Sage Publications.

Rambe, P. (2015). The role of educational technology in design and delivery of curricula programmes at a South African university:The case of STEPS at the Central University of Technology. The African Journal of Information System, 8(2), 86-113.

Salaway G., \& Caruso J. (2007). The ECAR Study of Undergraduate Students and Technology. EDUCAUSE, Boulder, CO.

Salter, D., Pang, M. Y. C., \& Sharma, P. (2009). Active tasks to change the use of class time within an outcomes based approach to curriculum design. Journal of University Teaching \& Learning Practice, 6(1), 26-38.

Saunders, M., Lewis, P. \& Thornhill, A. 2012. Research Methods for Business Students. 6th ed. England: Pearson Education Limited. 
Sharples, M., Adams, A., Ferguson, R., Gaved, M., McAndrew, P., Rienties, B., Weller, M., \& Whitelock, D. (2014). Innovating pedagogy 2014: exploring new forms of teaching, learning and assessment, to guide educators and policy makers. Retrieved April 20, 2016 from http://www.openuniversity.edu/sites/ www.openuniversity.edu/files/The_Open_University_Innovating_Pedagogy_2014_0. pdf

Shelly, G. B., Gunter, G. A., \& Gunter, R. E. (2012). Teachers discovering computers: integrating technology in a connected world. Cengage Learning.

Smith, S. D., \& Caruso, J. B. (2010). The ECAR Study of Undergraduate Students and Information Technology, 2010. Colorado: EDUCAUSE.

South African Technology Network (SATN) (2008). Universities of Technology in South Africa: Position, Role and Function.

Sperber, M. (2005). How undergraduate education became college lite-and a personal apology. In Hersh R. H., \& J. Merrow (Eds.), Declining by degrees: higher education at risk (pp. 131-143). New York: Palgrave Macmillan.

Walmsley, A. (2014). Unplug the Kids: Technology Isolates Children from Each Other and May Be Hampering Their Communication and Collaboration Skills. Phi Delta Kappan, 95(6), 80.

Warburton, S. (2010, June 15). Rhizome: Digital Identity matters. Retrieved November 19, 2014, from http://digitaldisruptions.org/rhizome/wpcontent/uploads/2010/06/rhiz08_DigitalIdentityMatters.pdf

Ward, A. (1990). Ideology, culture and the design studio. Design Studies, 11(1), 10-16.

Warger, T., \& Dobbin, G. (2009). Learning Environments: Where Space, Technology, and Culture Converge. EDUCAUSE Learning Initiative. Retrieved January 1, 2015 from https:// net.educause.edu/ir/library/pdf/ELI3021.pdf

West, M. A., Hafner, A. W., \& Faust, B. D. (2006). Expanding access to library collections and services using small-screen devices. Information technology and libraries, 25(2), 103-107.

Wheeler, S. (2012, November 16). Next generation learning [Web log message]. Retrieved May 10, 2014, from http://steve-wheeler.blogspot.com/ 2012/11/next-generationlearning.html

Witecki, G., \& Nonnecke, B. (2015). Engagement in Digital Lecture Halls: A Study of Student Course Engagement and Mobile Device use During Lecture, Journal of Information Technology Education: Research, 14, 73-90.

Yin, R.K. 2014. Case Study Research Design and Methods. Thousand Oaks, CA: Sage Publications.

Yumurtaci, O. (2017). A Re-Evaluation of Mobile Communication Technology: A Theoretical Approach for Technology Evaluation in Contemporary Digital Learning. Turkish Online Journal of Distance Education, $18(1), 213$ - 223. 